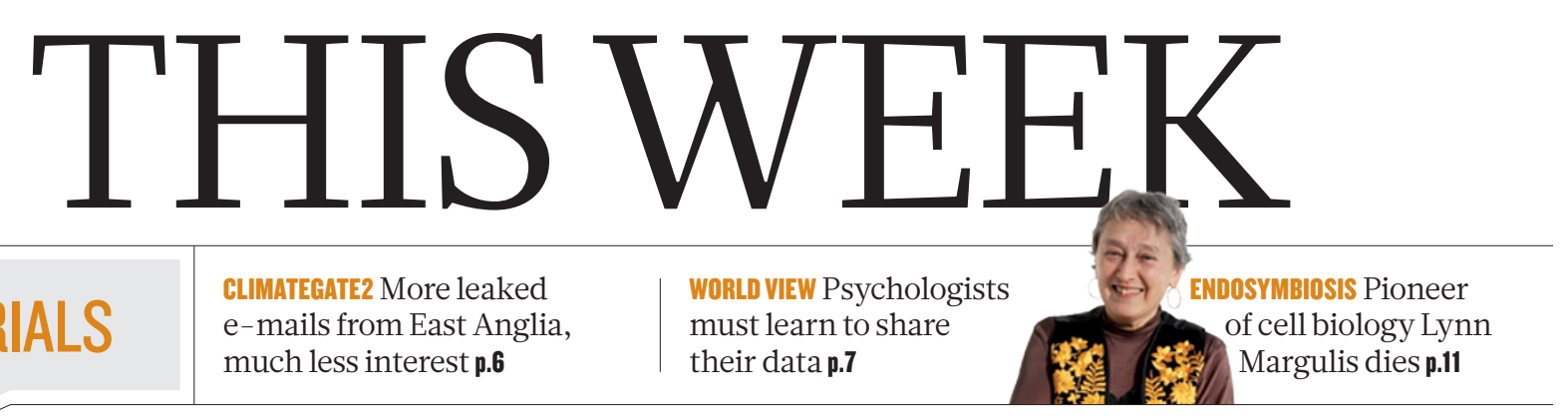

\section{EDITORIALS}

CLIMATEGATE2 More leaked much less interest $\mathbf{p . 6}$ must learn to share

their data $\mathbf{p . 7}$ of cell biology Lynn

Margulis dies p.11

\title{
Half way there
}

\section{Spain, Italy and Greece all have new governments and new research laws. Despite the pressures of economic austerity, investing in science now could bring disproportionate benefits.}

$\mathrm{T}$ Three of the Mediterranean countries hit hardest by the debt crisis - Spain, Italy and Greece - have little in common beyond a shared coastline and an inappropriately low level of investment in research and development. But in the past few years, all three have shown a desire to reform their sclerotic research systems. And in the past month, each has acquired, one way or another, a new government.

The priority for these governments is to haul their countries back from the brink of disaster, and thereby help to prevent the collapse of the euro. Given the enormity and international significance of these endeavours, does it make any sense to lobby for science to be favoured, financially and politically, in the tough austerity packages the new governments will have to enact?

It does, for two reasons. First, any developed country without a reasonable science base faces a bleak future - a familiar mantra, but true. Scientists in all three countries have for years seen little national money available for research projects, and almost no new academic recruitment. The best scientists have just about survived on international grants, particularly from the European Commission. Greek and Spanish researchers have the most to complain about, as austerity measures have cut into their pay packets, along with those of other civil servants in their countries. It is not hard to imagine that further cuts could lead to a dangerous level of demoralization.

Second, all three countries are now somewhere along the process of enacting or implementing new laws governing how research is organized and evaluated, which will bring them into line with scientific norms elsewhere in Europe. There is every reason to devote political resources to ensuring that these reforms are carried through properly - and, given that it won't cost much, little reason not to.

These Mediterranean countries have tended to be opaque in their science funding and academic recruitment, and so cronyism has often been able to rule over meritocracy. The new laws should help to fix this, primarily by introducing peer review and evaluation. In Spain and Greece, the new laws would also introduce for the first time muchneeded independent national agencies for the competitively allocated funding of basic research, along the lines of the European Research Council or the US National Science Foundation.

These laws have taken years of discussion - Greece's long-promised science law has not even been approved yet, although its university law was passed in August. In Italy, a law for research was approved at the end of 2009 and a law for universities one year later. Spain's science law was approved in June.

All these laws differ in scope and detail, and they are not perfect in every clause. In all three countries, for example, most academics will remain civil servants with jobs for life, disappointing those who had hoped that universities and publicly funded laboratories would gain more hiring flexibility. But whatever their shortcomings, if appropriately implemented, each of the laws will make science higher quality and better value for money.
All this matters even more because a handful of internationally competitive institutes, along with smaller pockets of excellence, have sprung up in each of these three countries, despite a lack of political support. The leaders of these institutes have chosen to operate through meritocracy; imagine how much will be achieved when this approach becomes mandatory for the entire scientific enterprise in
"Pockets of excellence have sprung up in each country, despite a lack of support." these countries.

Improvements in science in southern Europe will not only benefit the individual countries in which they occur, but will make Europe as a whole more competitive. Yet without new money, the legal frameworks may not be able to work the wonders expected of them. A new research funding agency won't be much help without a budget.

Now is not the time to expect huge increases in science investment, but small increases could make a disproportionate difference. Half way to reform, science in Spain, Italy and Greece needs to be supported. Like fiscal reform, it promises a long-term pay-off for those countries, and for the continent.

\section{False economy}

\section{The Danish government's plan to axe technology assessment is ill-conceived.}

L iberal democracy and science combined so successfully in the twentieth century that the nations and societies in which they were strongest rose to economic and cultural dominance. Nothing suggests that the recipe might lose its appeal as the twenty-first century proceeds, with democracy and science gaining ground in parts of the Arab world and some developing countries. But advances in science also raise ethical and environmental concerns that need to be taken seriously.

Denmark, a small but technologically advanced country that in January will take over the rotating presidency of the European Union, has pioneered the use of participatory methods to assess the risks and societal impact of new technologies. But plans to disband the Danish Board of Technology (DBT), which has been a leader in studying public views and expectations of science and technology, suggest that Denmark's new government is not quite aware of the country's formidable tradition in democratizing science. If it proceeds with the plan - which, ironically, is intended to preserve funds for research - it risks destroying a critical piece of Europe's science-policy system. 